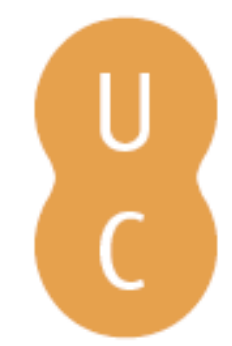

\title{
pommalina
}

\section{A disciple of Ronald Aylmer Fisher in Portugal: Wilfred Leslie Stevens in the Anthropological School of Coimbra during the early 1940's.}

Autor(es): $\quad$ Fonseca, Pedro Ricardo

Publicado por: Imprensa da Universidade de Coimbra

URL

persistente: URI:http://hdl.handle.net/10316.2/31279

DOI: $\quad$ DOI:http://dx.doi.org/10.14195/978-989-26-0342-1_10

Accessed : $\quad$ 26-Apr-2023 16:02:05

A navegação consulta e descarregamento dos títulos inseridos nas Bibliotecas Digitais UC Digitalis, UC Pombalina e UC Impactum, pressupõem a aceitação plena e sem reservas dos Termos e Condições de Uso destas Bibliotecas Digitais, disponíveis em https://digitalis.uc.pt/pt-pt/termos.

Conforme exposto nos referidos Termos e Condições de Uso, o descarregamento de títulos de acesso restrito requer uma licença válida de autorização devendo o utilizador aceder ao(s) documento(s) a partir de um endereço de IP da instituição detentora da supramencionada licença.

Ao utilizador é apenas permitido o descarregamento para uso pessoal, pelo que o emprego do(s) título(s) descarregado(s) para outro fim, designadamente comercial, carece de autorização do respetivo autor ou editor da obra.

Na medida em que todas as obras da UC Digitalis se encontram protegidas pelo Código do Direito de Autor e Direitos Conexos e demais legislação aplicável, toda a cópia, parcial ou total, deste documento, nos casos em que é legalmente admitida, deverá conter ou fazer-se acompanhar por este aviso.

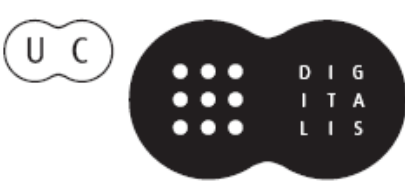


Ana Leonar Pereira João Rui Pita

Pedro Ricarda Fonseca (eds.)
Darwin,

Evalution,

Evolutionisms

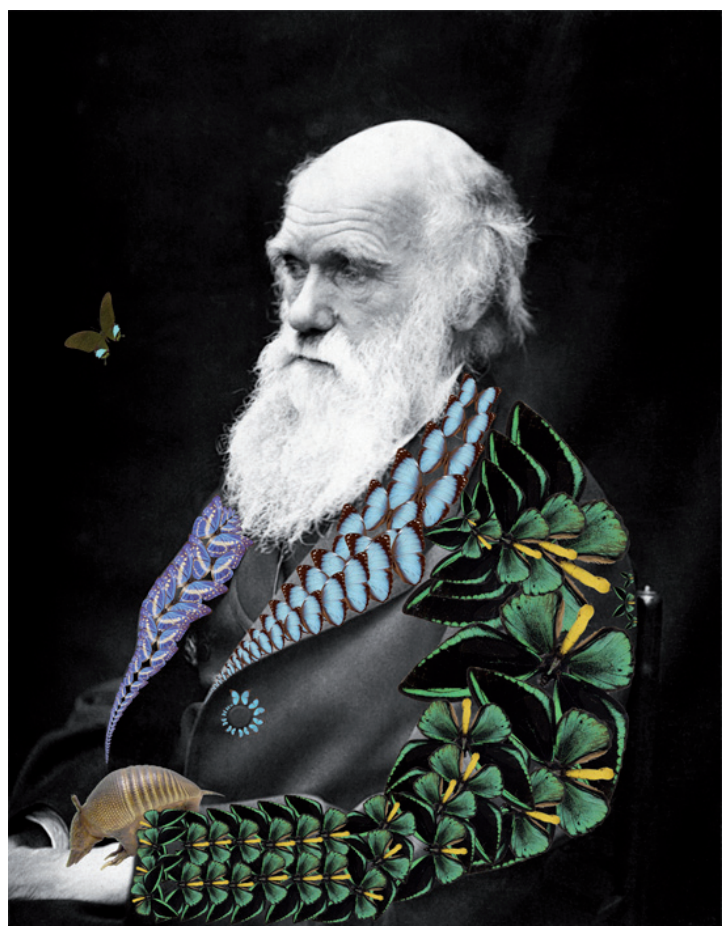


Pedro Ricardo Fonseca

FCT; Faculdade de Letras, CEIS20-Grupo de História e Sociologia da Ciência,Universidade de Coimbra, Portugal

\section{A disciple of Ronald Aylmer Fisher in Portugal: Wilfred Leslie Stevens in the Anthropological SCHOOL OF CoImbra during THE EARly 1940's.}

The present work studies Wilfred Leslie Stevens' (1911-1958) presence at the Anthropological Institute of the University of Coimbra during the early 1940's. Who was Wilfred Leslie Stevens? Why was he assigned? What analysis can be made of his passage through Coimbra? It was around these three questions that we elaborated our work, in an effort to locate and structure information which, on the one hand, would allow us to obtain partial and temporary answers, and, on the other hand, would favour the emergence of new topics of interest and new questions.

Who was Wilfred Leslie Stevens? Despite having carried out an extensive bibliographical research, we were unable to locate a biography or biographical summary on W. L. Stevens. The following information is, thus, the result of the conjugation of elements collected from diverse sources, including data provided by people that work at institutions to which Stevens was connected to during his lifetime. ${ }^{1}$ Wilfred Leslie Stevens was born on the $25^{\text {th }}$ of June 1911 . He studied at the University of Reading and at the University of Cambridge, ${ }^{2}$ where he obtained his bachelor's degree in Mathematics. ${ }^{3}$ In June 1935, he initiated his $\mathrm{PhD}$ in eugenics at University College London (UCL), where he was assistant professor in the department of eugenics from October 1934 until June 1937, and professor from 1937. ${ }^{4}$ It was at the Galton Laboratory of UCL that Stevens worked under the guidance of Ronald Aylmer Fisher (1890-1962) between 1935 and 1941. In 1941, due to urgent works of war, Stevens joined the department of statistics of the experimental station of Rothamsted for a few months, before moving

1 We wish to express our profound gratitude to Dayaram Nakrani and Wendy Butler of University College London (UCL), Hans Lucas and G. J. Stemerdink of the International Statistical Institute (ISI), Suzanne of the International Biometric Society (IBO), Peter Bloor from the British Council, and Professor Décio Barbin, for their valuable help.

${ }^{2}$ Information generously provided by Wendy Butler of the Senior Records Office of University College London (UCL), (28/05/2009).

3 See: Boletim da Associação Brasileira de Estatística, Ano XVIII, No 52, 20 Quadrimestre de 2002, p. 43. Available at: http://redeabe.org.br/Boletins/Boletim_52.pdf (24/05/2009)

${ }^{4}$ Information generously provided by Wendy Butler of the Senior Records Office of University College London (UCL), (28/05/2009). 
to Portugal. ${ }^{5}$ His passage through Portugal is the main object of study of the present work and will be, thus, the object of a more detailed analysis. In 1947, Stevens was hired to ensure the leadership of the discipline "Mathematical Statistics and Demographical Statistics" of the Faculty of Economy and Administration of the University of São Paulo (Brazil), where he was a professor between 1948 and 1958. The elaboration of the statistical tables of R. A. Fisher and Frank Yates (1902-1994), published in 1938, benefited from the assistance of Stevens, ${ }^{6}$ which, besides that, published dozens of articles in specialized magazines of statistics, eugenics and biometrics, as, for example: Annals of Eugenics, Journal of Genetics, Journal of the Royal Statistical Society B and Biometrika. ${ }^{7}$ Elected member of the International Statistical Institute (ISI) in $1952,{ }^{8}$ Wilfred Leslie Stevens passed away in 1958.

Why was W. L. Stevens hired? The hiring of the British statistician was part of the path which one of Portugal's leading anthropologists, Eusébio Tamagnini (1880-1972)9 had outlined for Anthropology in Portugal and, in particular, for the Anthropological School of Coimbra, during the early 1940 's, i.e. only a couple of years before W. L. Stevens was hired. In 1940, Eusébio Tamagnini, along with José Antunes Serra (1914-1990) mentioned the approach of physical anthropology (the anthropological branch then predominant, as opposed to cultural or ethnological anthropology $)^{10}$ to biology, and, in particular, to genetics. This approximation, illustrated by the progressive amount of the number of biologists dedicating themselves to physical anthropology (contradicting the traditional predominance of physicians), is connected to methodological issues, with research works demanding the use of "rigorous statistical methods in judging the data and in the comparison of the various populations, along with the results of the studies on the heredity of human features". ${ }^{11}$ E. Tamagnini and J. A. Serra defined the development of these studies as "one of the current purposes of the Institute

\footnotetext{
${ }^{5}$ See: "Mathematical Statistics at the University of Sao Paulo: Mr. W. L. Stevens", In: Nature 162, 56-56 (10th July 1948). Available at: http://www.nature.com/nature/journal/v162/n4106/abs/162056c0.html (28/05/2009)

${ }^{6}$ See: José Maria Pompeu Memória, Breve História da Estatística, Brasília, Df, Embrapa Informação Tecnológica, 2004, p. 52. Available at: http://www.im.ufrj.br/ lpbraga/prob1/historia_estatistica.pdf (24/05/2009).

7 Until 1947, the year he was hired by the University of São Paulo, Stevens had published more than twenty articles in the magazines already mentioned. Cf. Boletim da Associação Brasileira de Estatística, Ano XVIII, No 52, $2^{\circ}$ Quadrimestre de 2002, p. 43. Available at: http://redeabe.org.br/Boletins/Boletim_52. pdf $(24 / 05 / 2009)$

${ }^{8}$ Information generously provided by Hans Lucas of the International Statistical Institute (ISI), $(26 / 05 / 2009)$.

${ }^{9}$ On the history of the anthropological school of Coimbra, under the leadership of Eusébio Tamagnini, see, for example: Gonçalo Duro dos Santos, A Escola de Antropologia de Coimbra 1885-1950: o que significa seguir uma regra cientifica?, Lisboa, Imprensa de Ciências Sociais, 2005, especially pp. 122-174. (the work includes a biography, pp. 206-209., and a complete bibliographical list, pp. 226-232., of Eusébio Tamagnini); and Cem anos de antropologia em Coimbra 1885-1985, Coimbra, Museu e Laboratório Antropológico, 1985, especially pp. 18-22. (the book contains a detailed chronology on the anthropology at the University of Coimbra, pp. 227-233)

10 See: E. Tamagnini and J. A. Serra, Subsidios para a história da antropologia portuguesa (Memória apresentada ao Congresso da Actividade Científica Portuguesa, Coimbra, 1940), Coimbra, 1942, p. 7.

${ }^{11}$ Idem, ibidem, p. 12. - our translation from the Portuguese text.
} 
of Anthropology", ${ }^{12}$ to which they assigned, in line with the eugenic thought dominant at the time, a valuable practical application: "the eugenic and population studies constitute the basis of the indispensable social reforms for the enhanced future life of humanity" ${ }^{13}$ It is in this context of the necessity to improve the statistical treatment of anthropometric, physiological and demographic data, that one understands the arrival of W. L. Stevens, assigned "as a statistician, to guide the application work of modern statistical methods to Biological Sciences and organize initiation courses for professors and students of the same methods". ${ }^{14}$ The "Elementary Course of Modern Statistical Methods applicable to Scientific Investigation", headed by professor W. L. Stevens, functioned between 1942 and 1944, and is linked to a set of published studies in the series "Questôes de Método". ${ }^{15}$ It is importance to add that in hiring a "distinct student of Professor R.A. Fischer", ${ }^{16}$ E. Tamagnini could count with the intervention of the British Council and the "Instituto para a Alta Cultura". ${ }^{17}$ This last institution provided a subsidy of 16000 escudos (Portuguese currency at the time) for the functioning of the course headed by W. L. Stevens. ${ }^{18}$

What analysis can be made of W. L. Stevens' passage through Coimbra? First, it is important to highlight that the Anthropological School of Coimbra could benefit, even if only for a limited period of time, from the services of a disciple of Ronald Aylmer Fisher a celebrated scientist with important contributions to mathematics, statistics, biometrics and evolutionary biology (with a decisive role in the progressive conciliation between Mendelism and Darwinism, R. A. Fisher is one of the founders of population genetics and one of the main contributors to the Modern Synthesis). ${ }^{19}$ As for the years W. L. Stevens spent in Coimbra, the data which allows us to inquire about his teaching activity is frankly scarce. We know that the course he led functioned between 1942 and 1944, but the apparent absence of Stevens' curriculum vitae in the archives of the University of Coimbra, and, mainly, the inexistence of annuals

12 Idem, ibidem, p. 13. - our translation from the Portuguese text.

13 Idem, ibidem, pp. 13-14. - our translation from the Portuguese text.

${ }^{14}$ Diário do Governo, 11 th December 1942. Quoted by: Cem anos de antropologia em Coimbra 1885-1995, Coimbra, Museu e Laboratório Antropológico, 1985, p. 21. - our translation from the Portuguese text. The course's subject areas were mathematics, biology, medicine, psychology, genetics, physics, chemistry and agriculture. Cf. Revista da Faculdade de Ciências da Universidade de Coimbra, Coimbra, Tipografia da Atlântida, vol. X, n², 1942, p. 308.

15 See: Cem anos de antropologia em Coimbra 1885-1995, Coimbra, Museu e Laboratório Antropológico, 1985 , p. 21.

${ }^{16}$ Eusébio Tamagnini. Quoted by: Gonçalo Duros dos Santos, 2005, p. 211.

17 See: Gonçalo Duro dos Santos, 2005, p. 211; Revista da Faculdade de Ciências da Universidade de Coimbra, Coimbra, Tipografia da Atlântida, vol. X, No2, 1942, pp.293-294. British official sources confirm the intervention of the two identities in the process. Cf. The British Council Annual report for 1941-42 - information generously provided by Peter Bloor, Records Management Officer, The British Council, (1/6/2009).

${ }^{18}$ See: Revista da Faculdade de Ciências da Universidade de Coimbra, Coimbra, Tipografia da Atlântida, vol. X, nº2, 1942, p. 302.

19 The evolutionary biologist and popular science writer Richard Dawkins ranks R. A. Fisher as Darwin's great $20^{\text {th }}$ century successor. Cf. R. Dawkins (ed.), The Oxford Book of Modern Science Writing, Oxford, New York, Oxford University Press, 2008, pp. 18-19. 
of the same institution for the period between 1943 and 1947 (encompassing, thus, the years during which the course led by W. L. Stevens was lectured), conditioned our investigation. What was the programme of the course? Who attended it? What bibliography was recommended? Why was it extinct after only two years? These are just some of the questions that (at least) for now, will remain without an answer. As for W. L. Stevens' scientific activity, the English statistician published many articles during his short stay in Portugal - due to the limited length of the present text, these works will not be mentioned here. It is also important to highlight that, although in Portugal, W. L. Stevens' master, R. A. Fisher, did not forget him, revealing himself informed about some important progresses made by contemporary Portuguese naturalists. On the $29^{\text {th }}$ July 1944 , R. A. Fisher wrote to W. L. Stevens requesting the latter to send him examples of the three species of tristyly plants which had been identified by the Portuguese botanist Abílio Fernandes (1906-1994). ${ }^{20}$

20 See: http://digital.library.adelaide.edu.au/coll/special//fisher/corres/stevenswl/StevensWL440729a. html (28/05/2009). 